\title{
CONSIDERAÇÕES SOBRE A LAICIDADE BRASILEIRA A PARTIR DA CRIMINALIZAÇÃO DAS EXPRESSÕES RELIGIOSAS DAS TRADIÇÕES DE MATRIZ AFRICANA.
}

\author{
Considerations about the brazilian secularity from the criminalization of religious \\ expressions of the African matrix traditions
}

\author{
Winnie de Campos Bueno \\ Mestranda em Direito pela Universidade do \\ Vale do Rio dos Sinos (UNISINOS). \\ Iyalorixá do Ilê Aìyé Orishá Yemanjá - Pelotas/RS \\ Márcia Rodrigues Bertoldi \\ Doutora em Direito pelas Universidades \\ Pompeu Fabra de Barcelona (UPF) e \\ de Girona (UdG) - (Rev. UFSC em 2004), \\ Pós-Doutorado UNISINOS. Professora do curso de \\ Direito da Universidade Federal de Pelotas.
}

RESUMO: O racismo institucional compõe as relações sociais no Brasil, manifestando se nas esferas pública e privada, é um fator limitante na conquista de direitos sociais. Atravessa o histórico do território brasileiro e, consequentemente, influencia o desenvolvimento e a organização estatal. Nesse sentido, é cabível dizer que o racismo institucional permeia a construção da laicidade no Brasil. A separação Estado - Igreja no Brasil se deu com influência dos processos de laicização europeus, especialmente o francês. Contudo a moral e os valores cristãos continuaram a influenciar a presença pública do sagrado no Brasil, resultando em uma hegemonia dos pressupostos civilizatórios judaico-cristãos em detrimento daqueles baseados em tradições dos povos indígenas e de origem negro-africana. O histórico do Direito brasileiro, especialmente nas legislações de Direito Penal e Constitucional, demonstra que a restrição ao livre exercício religioso é intimamente ligada ao controle social da população negra. Dessa forma, recaem sobre as tradições religiosas de matriz africana as criminalizações oriundas dos dispositivos legais que limitam a liberdade religiosa. Considerando que a laicidade se configura visando a não existência de prevalência de convicções, um cenário que possibilite a existência de todas estas no espaço público, a premissa deste trabalho é inquerir sobre o tratamento que as expressões religiosas das tradições de matriz africana têm recebido na esfera pública e se esse tratamento é resultado da permanência do racismo institucional no Estado brasileiro. Esse trabalho utiliza-se do método de abordagem dedutivo, tem caráter de pesquisa qualitativa e está construído sob as bases da análise bibliográfico-documental.

Palavras-chave: Laicidade; Racismo Institucional; Liberdade de culto

ABSTRACT: Institutional racism, which comprises social relations in Brazil and whose manifestation is widespread in the public and private spheres, is a limiting factor in the achievement of social rights. Institutional racism traverses the history of the Brazilian territory and, as a consequence, influences development and organization of the state. Therefore, it is reasonable to postulate that institutional racism permeates the construction of secularism in Brazil. Separation of church and state in Brazil was influenced by the processes of European secularization, especially by the French process. Christian morality and values, however, continued to influence the presence of the sacred in Brazil, resulting in a hegemony of Judeo-Christian civilizational presuppositions to the detriment of those based on traditions 
of indigenous peoples and those of Black African origin. Historical court records from the Brazilian Legal System, especially within Criminal and Constitutional laws, demonstrate that restriction on religious freedom is closely linked to social control of the black population. Thus, criminalization policies resulting from the legal provisions that limit religious freedom befall the religious traditions of African origin. Considering that secularism is configured in such a way as to avoid the occurrence of prevalence of convictions - a scenario which should enable the occurrence of all convictions in the public sphere - the premise of this work is to inquire into the treatment that the religious expression of traditions of African origin has received in the public sphere and whether that treatment results from the continued existence of institutional racism in the Brazilian government. Deductive approach methodology has been used in this work, which is qualitative in nature and theoretically grounded through literature review and document analysis.

Keywords: Secularism; Institutional Racism; Religious Freedom. 


\section{Introdução}

A influência religiosa cristã na esfera pública brasileira é uma construção histórica que eterniza pressupostos morais hegemonicamente marcados por um conteúdo valorativo de cunho eurocêntrico. O aspecto público dos segmentos da política é contaminado por ações e discursos que revelam a fragilidade da construção da laicidade, sendo frequentes os questionamentos sobre a permanência das representações simbólicas do cristianismo nos prédios públicos, vez que revelam os conteúdos morais que são imprimidos às decisões proferidas nestes espaços, as quais não deveriam ser influenciadas por pressupostos de cunho religioso, visto a vigência dos fundamentos da laicidade estatal (GONÇALVES,2011).

A ausência de mecanismos suficientes para consolidar o estado laico e a liberdade religiosa no Brasil, bem como a prevalência de único pressuposto moral em um país marcado pelo multiculturalismo e pela pluralidade de cosmovisões, naturaliza a criminalização das expressões religiosas de matriz africana. Segundo dados de relatório produzido pela Assembleia Legislativa do Estado do Rio de Janeiro (ALERJ), entre os anos de 2012 e 2014 alcançou-se o número de 948 casos de intolerância religiosa apenas nesse estado. ${ }^{1}$

A partir da análise do projeto de lei proposto pela deputada estadual Regina Becker Fortunati, no ano de 2015, no estado do Rio Grande do Sul, desenvolveu-se o presente artigo, possibilitando um estudo ampliado sobre o histórico da laicidade na esfera do Direito Constitucional e, ainda, apreciando os limites à liberdade religiosa a partir do exame de dispositivos infraconstitucionais que cercearam a visibilidade das expressões religiosas de matriz africana.

Esse trabalho utiliza-se do método de abordagem dedutivo, tem caráter de pesquisa qualitativa e está construído sob as bases da análise bibliográfico-documental.

\section{Breves apontamentos sobre a construção da laicidade no constitucionalismo brasileiro.}

O histórico do direito constitucional brasileiro é intrínseco aos conteúdos valorativos de caráter eurocêntrico, sendo este uma consequência do processo de colonização, o qual tinha por objetivo não apenas uma expansão territorial, mas também

\footnotetext{
1 Dados disponíveis em: http://g1.globo.com/rio-de-janeiro/noticia/2015/08/ri-registra-mil-casosdeintolerancia-religiosa-em-2-anos-e-meio.html
} 
o fortalecimento da fé católica, portanto as expedições marítimas que ocasionaram a conquista do território brasileiro no século XVI contaram com o fomento político e financeiro da Santa Sé (CASAMASSO, 2010). Os movimentos políticos e sociais que ocorreram na Europa, influenciaram a redação das constituições brasileiras, ocasionando na produção de instrumentos legislativos que, frequentemente, refletem contextos estrangeiros. Logo, a própria construção da laicidade no Brasil é influenciada pelos aspectos históricos e sociais que estabeleceram os fundamentos do estado laico em países estrangeiros.

A primeira Constituição pátria surgiu com forte influência do constitucionalismo liberal, a principal característica era o forte centralismo administrativo e político, consolidado na figura do Poder Moderador (LENZA, 2013). No que tange à questão religiosa, adotava-se o catolicismo enquanto religião oficial, tendo a Igreja relações estreitas com o Império, embora fossem permitidas expressões religiosas distintas desde que seu exercício se desse na esfera privada.

Essa vedação à exteriorização da fé distinta da religião católica permite considerações sobre outros preceitos fundamentais do constitucionalismo clássico, como a cidadania. A noção de cidadania no Brasil Imperial estava adstrita à pertença religiosa. A descrição de SCHWARTZMAN apud RANQUETAT JÚNIOR (2012, pág. 48.) é precisa na análise dessa questão:

[...] o grupo religioso hegemônico controlava e influenciava direta ou indiretamente, importantes setores da esfera pública (escolas, hospitais etc.), e as principais instituições sociais. Detinha o monopólio dos principais atos cívicos e ritos de passagem (batismo, casamento, enterro). Assim, ser cidadão no Brasil era quase sinônimo de ser católico.

A literalidade do artigo $5^{\circ}$ da Constituição do Império marca o acolhimento do catolicismo na esfera pública brasileira, desde os primórdios do Direito Constitucional, cujos valores permanecem ditando normas jurídicas desde a conquista do território até a atualidade, conferindo a legitimidade social gozada por esta religião.

A proclamação da República, em 1889, gestou a redação da primeira Constituição Republicana, a qual caracteriza-se pelo fim de uma religiosidade oficial. A 
retirada dos efeitos civis do casamento religioso, o controle dos cemitérios por parte da administração municipal, a proibição do ensino religioso nas escolas públicas e a própria ausência das menções a Deus no preâmbulo da Constituição demonstram a disposição em romper as relações políticas com a Igreja. As experiências de laicidade em outras nações, marcadamente na França, facilitaram a inserção deste pressuposto no texto constitucional enquanto princípio fundamental. Contudo, a moral e os valores cristãos continuaram a influenciar a presença pública do sagrado no Brasil.

Embora a Igreja Católica tenha se fragilizado enquanto instituição política, a fé cristã eurocêntrica continua sendo aceita na esfera pública, enquanto as expressões religiosas das tradições de matriz africana seguem sendo exercidas no contexto privado. Destaca-se que a própria Igreja Católica não apresentava óbices à inserção do fundamento da liberdade religiosa na Constituição. Para a Igreja havia uma possibilidade de autonomia que não era exercida no período imperial. Conforme GIUMBELLI (2008, pág. 82.):

[..] é imperativo destacar que a mesma Igreja Católica que foi contra a separação se colocou a favor da liberdade. A traduzir o princípio, estavam em jogo discussões sobre a autonomia jurídica das instituições religiosas. A lei de 1890 produziu a separação entre Estado e Igreja Católica reconhecia "a todas as igrejas e confissões religiosas a personalidade jurídica para adquirirem os bens e os administrarem", mas "sob os limites concernentes à propriedade de mão- morta" Já na Constituição de 1891, venceu a seguinte formulação, com o apoio das forças católicas : “Todos os indivíduos e confissões religiosas podem exercer publicamente o seu culto, associando-se para o seu fim e adquirindo bens, observadas as disposições do direito comum.

Fica evidente que no jogo político protagonizado pela Igreja Católica e pelo Estado Republicano, houve concessões de ambas as partes. Se por um lado erige -se um Estado laico, por outro a instituição da liberdade religiosa é configurada a partir de interesses da própria Igreja, que adquire autonomia econômica e jurídica.

A Constituição de 1934, reinsere os valores morais cristãos no texto magno. Retoma-se o ensino religioso nas escolas e a validade do casamento religioso no âmbito 
civil. Pode-se, aqui, observar um retrocesso, visto a incompatibilidade da existência de um currículo religioso no qual sabidamente apenas os preceitos do cristianismo são repassados (CURY,2004). O restabelecimento do diálogo Estado e Igreja consubstancia-se enquanto uma resposta ao sentimento antirreligioso, havendo uma política de conciliação entre estas instituições. A reflexão se dá a partir de uma constatação do cenário atual da sociedade brasileira, onde ainda encontramos resistência à inserção de disciplinas escolares que versem sobre outras tradições religiosas e ao reconhecimento de casamentos religiosos diversos daqueles cuja a liturgia é calcada nos preceitos judaico-cristãos. (ORO, 2011).

O decorrer do histórico do constitucionalismo brasileiro é marcado pela permanência das beneficies concedidas pelo Estado à Igreja Católica. As constituições que se seguiram continuaram estabelecendo a separação Estado-Igreja, constituindo a nação formalmente enquanto laica, mas instituindo a cooperação Estado- Igreja.

Nesse sentido, a presença dos símbolos religiosos cristãos nas esferas públicas brasileiras de forma exclusiva coloca em contradição a laicidade. Embora sendo uma nação não confessional, o cotidiano do Judiciário, Legislativo e Executivo brasileiro é influenciado pela presença dos valores morais do cristianismo, apontando para a falta de isonomia no tratamento destinado a outras religiões, uma vez que o Estado assegura privilégios para a presença pública do cristianismo (ORO, 2011).

Embora não exista laicidade plena, e considerando que os diferentes processos de laicização são correspondentes aos diferentes desenvolvimentos dos Estados, conforme a própria Declaração Universal da laicidade no século $\mathrm{XXI}^{2}$, a criminalização e perseguição de determinadas expressões religiosas é incompatível com o Estado laico. Ademais, a laicidade pressupõe um tratamento equânime entre as diferentes expressões religiosas, o que não ocorre no Brasil pelo menos até a outorga da Constituição de 1988, onde se erige a liberdade religiosa como princípio fundamental, mas que, conforme veremos adiante, não se consolida de forma material.

2 Declaração apresentada por Jean Baubérot (França), Micheline Milot (Canadá) e Roberto Blancarte (México) no Senado Francês, em 9 de dezembro de 2005, por ocasião das comemorações do centenário da separação Estado-Igrejas na França. Disponível em: http://www.edulaica.net.br/artigo/186/biblioteca/documentos-coletivospelalaicidade/declaracao-universal/ 


\section{As limitações à livre expressão religiosa através da criminalização das tradições de matriz africana.}

A liberdade religiosa é um princípio fundamental que possibilita a construção da identidade e subjetividade dos sujeitos. Embora seja considerada enquanto aspecto subjetivo, ela se manifesta de forma coletiva, em especial, no que tange às tradições de matriz africana, cuja visão de mundo está alicerçada em princípios civilizatórios, nos quais o direito individual se consubstancia no conjunto dos direitos constitutivos da comunidade. As limitações ao livre exercício religioso criam óbices à efetivação da democracia. Portanto, é necessário enfrentar este conflito para que se possa avançar na construção de um Estado Democrático de Direito capaz de reparar o histórico de supressão de garantias fundamentais que foi experimentado por um número significativo de brasileiros e brasileiras.

As graves violências experimentadas pela população negra remetem à escravização. Estas marcas estão inseridas também na construção da laicidade do Estado e da liberdade religiosa, pois são as tradições de matriz africana que sofreram os atravessamentos promovidos por controles e limitações estatais que impediram a plenitude do exercício democrático de crença e pertencimento. A laicidade pode ser definida como o "modo de organização política que visa à proteção da liberdade de consciência e à igualdade dos cidadãos" (BAUNEROT e MILLOT apud NICOLINI, 2011, pág.236), portanto as limitações à esta liberdade de consciência são contraditórias ao Estado laico.

Importante destacar que as tradições de matriz africana experimentaram a criminalização constante desde os primórdios do judiciário brasileiro, consequência da hegemonia do pensamento ocidental judaico-cristão eurocêntrico. A produção do conhecimento nas academias também contribuiu para a formação do ideário hegemônico responsável pelo processo de criminalização das práticas originárias da tradição de matriz africana, através da difusão de resultados de pesquisas ${ }^{3}$ que contribuíram para a consolidação da penalização das mesmas.

Os artifícios criados por um Estado que se pretendia enquanto laico para

\footnotetext{
No final do século XIX e na primeira metade do século XX, predominava nas academias brasileiras estudos centrados no racismo científico e na criminologia bioética, através dos quais reverberou-se a ideia de que os negros seriam uma raça inferiorizada, ausente de possibilidades de civilidade. Através destes estudos direcionou-se as políticas públicas de saúde na época, marcadas por uma visão higienista de sociedade através da eugenia do branqueamento da população brasileira. (GUTMAN, 2007)
} 
subjugar as tradições de matriz africana não se limitaram aos empecilhos para a realização dos cultos religiosos. É, nesse sentido, que se estabelece o Decreto 20930/1932, na vigência do Estado Novo, estabelecendo a fiscalização da comercialização e uso das substâncias tóxicas e entorpecentes, entre elas a maconha, que estava diretamente relacionada com a cultura de matriz africana. O que temos nesse período é a tentativa de uma política de embranquecimento eurocêntrico do país. Segundo SAAD (2013, pág.90):

[...] foi a partir de 1920, ano da criação do Departamento Nacional de Saúde Pública, que foi se fortalecendo o movimento sanitarista brasileiro. O controle e extinção das doenças contagiosas visavam não apenas proteger a saúde do trabalhador brasileiro, mas estimular a entrada de imigrantes europeus - assustados com o alto índice de febre amarela -, indispensáveis para a modernização do país através de seu embranquecimento, ao passo em que diminuiriam os efeitos da miscigenação racial. [...]. Ideologicamente, o período foi caracterizado pelo abandono dos ideais liberais, direcionado ao controle social e voltado a um pensamento autoritário, influenciado pelo totalitarismo europeu. A modernização conservadora inaugurada com o movimento de 1930 prometia um novo começo em um país que deveria se renovar através de um regime político diferente com base na formação de um novo homem brasileiro. $\mathrm{O}$ controle sobre os entorpecentes e, principalmente, sobre determinados costumes que seguiam o caminho contrário ao progresso tornava-se cada vez mais forte e indispensável aos anseios na nova conjuntura. Em janeiro de 1932, a criminalização da maconha se deu através do Decreto 20.930, responsável por coibir "o emprego e o comércio das substâncias tóxicas entorpecentes". A lei detalhava que se proibia "fabricar, importar, exportar, reexportar, vender, trocar, ceder, expor ou ter" maconha, e para seu eventual uso médico seria "indispensável licença especial da autoridade sanitária competente". A venda estaria restrita às farmácias devidamente autorizadas e as receitas aos médicos formalmente diplomados, restando ainda uma brecha para o comércio e consumo da planta, embora não haja indícios de que sua utilização medicinal tenha perdurado após a proibição.

O histórico de limitações ao livre exercício religioso em leis infraconstitucionais é decorrência do racismo institucional, visto que se destinavam ao controle das formas de expressar o sagrado nas tradições de matriz africana, as quais são interpretadas de forma pejorativa, sendo o culto aos orixás considerado como um traço da ignorância dos descendentes de escravizados africanos. O controle ideológico exercido pela Igreja Católica é parte fundamental da consolidação das leis que limitavam o livre exercício religioso. Sabe-se que toda a norma explicita um dever-ser 
social composto por um conteúdo moral. Este conteúdo, no que diz respeito à criminalização das tradições de matriz africana, se liga à necessidade de fortalecer a hegemonia judaico-cristã no território brasileiro.

Os dados da Cartilha Contra a Intolerância Religiosa ${ }^{4}$, organizada pelo Centro de Estudos das Relações de Trabalho e Desigualdade, apontam o histórico de legislações que contribuíram para a consolidação da intolerância religiosa a partir da criminalização de cultos distintos do catolicismo. O Código Criminal do Império, de 1830, considerava crime o culto de religião que não fosse a oficial; a zombaria contra a religião oficial; a manifestação de qualquer ideia contrária à existência de Deus. Tais delitos eram previstos na quarta parte do dispositivo jurídico, que tratava dos crimes policiais ${ }^{7}$. Logo, a manifestação pública de qualquer religião divergente da cristã era criminalizada. A possibilidade de destruir templos e símbolos que não estivessem em conformidade com a moral hegemônica, acabou por tornar cotidiano o vilipêndio que até hoje estão sujeitos os terreiros e casas de santo. Conforme PINTO (2011, pág.2):

O direito se torna o campo de legitimação da hegemonia. A lei é redefinida como instrumento de disciplina, controle e hierarquização. Embora os princípios da Escola Penal Clássica, principal influência normativa do Código Criminal Imperial, busque desvincular a relação entre infração e falta moral ou religiosa, isso não aconteceu plenamente. As ofensas à moral e à religião são as maiores causas de encarceramento nos crimes considerados policiais.

As expressões socioculturais negras representavam uma afronta ao ideário de civilidade que buscavam as elites brasileiras. Não obstante, os terreiros possibilitavam a reunião de um número considerável de negros e negras escravizados que se articulavam politicamente na gestação do processo abolicionista (REIS apud SANTOS, 2011).

Após o advento da República, nasce o Código Penal de 1890 diante da

$4 \quad$ Disponível

em:

www.defensoria.sp.gov.br/dpesp/Repositorio/39/Documentos/cartilha intolerancia reli giosa.pdf ${ }^{7}$ PARTE QUARTA Dos crimes policiais. CAPÍTULO I: OFFENSAS DA RELIGIÃO, DA MORAL, E BONS COSTUMES. Art. 276. Celebrar em casa, ou edifício, que tenha alguma fórma exterior de Templo, ou publicamente em qualquer lugar, o culto de outra Religião, que não seja a do Estado. Penas - de serem dispersos pelo Juiz de Paz os que estiverem reunidos para culto; da demolição da fórma exterior; e de multa de dous a doze mil réis, que pagará cada um. (BRASIL, 1830) 
necessidade de reconfiguração dos ordenamentos jurídicos à nova conformação política brasileira. As elites preocupadas com a manutenção dos seus privilégios, ocuparam-se em manter a população distante do exercício da democracia. Logo, o que se tinha efetivamente era uma República apartada da população e de seus anseios. O Código Penal de 1890 trazia expressamente a criminalização das práticas de curandeirismo, conforme o artigo 158, reproduzido ipsis litteris:

Art. 158. Ministrar, ou simplesmente prescrever, como meio curativo para uso interno ou externo, e sob qualquer fórma preparada, substancia de qualquer dos reinos da natureza, fazendo, ou exercendo assim, o officio do denominado curandeiro: (BRASIL,1890)

Decerto, em uma tradição na qual o sagrado e o profano formam uma unidade indivisível e as relações com a natureza são essenciais para a vida dos seus fiéis, inclusive havendo saberes ligados a cura de doenças, através de ervas e chás, as religiosidades de matriz africana eram associadas ao curandeirismo e, portanto, criminalizadas. Embora as práticas das expressões religiosas de matriz africana não fossem criminalizadas conforme a letra fria da lei, eram os adeptos dessas tradições que se sujeitavam às incriminações do curandeirismo (OLIVEIRA, 2012). A criminalização de simbolismos relacionados à identidade negra não se restringe às manifestações religiosas. É na mesma esfera em que se criminaliza os ritos religiosos de origem africana que se criminalizou a capoeira e o uso da maconha, por exemplo. São aspectos distintos de uma mesma estratégia de atribuição de determinados signos aos seres negros, consolidando a forma com que se estabelece o sentido social de raça no Brasil. (SAAD, 2013)

A ideia de que manifestações religiosas, culturais e sociais das tradições de matriz africana seriam praticadas em espaços insalubres e propícios à insanidade mental se perpetuou através de estudos científicos acadêmicos, em especial os desenvolvidos pelo médico Nina Rodrigues ${ }^{5}$, que desenvolveu estudos de campo em terreiros de candomblé na Bahia. O pesquisador retratou o cotidiano do candomblé, porém, a partir de uma perspectiva calcada no racismo científico que estava em voga na academia

\footnotetext{
$5 \quad$ Especialmente nas obras Os africanos no Brasil (1932) e O animismo fetichista dos negros baianos (1935).
} 
brasileira à época. Nina considerava que estes cultos demonstravam a involução dos negros africanos e sua inferioridade mental, física e religiosa. Segundo seus estudos, o transe experimentado nesses espaços territoriais era um sinal de histeria e a existência de negros no território brasileiro seria uma marca que consolidaria a inferioridade do país em relação à Europa. Estudos como o de Nina Rodrigues foram fundamentais para que se estabelecessem políticas de invisibilidade e eliminação das pertenças socioculturais da negritude no Brasil, repercutindo em uma escola de pensadores que comungavam de suas ideias. ${ }^{6}$

A criminalização das práticas entendidas como curandeirismo reside também em uma espécie de reserva de mercado por parte da intelectualidade médica brasileira, conforme explica GIUMBELLI (2003, pág. 254):

A criminalização do espiritismo, alegando-se a proteção à saúde pública, deve ser entendida no contexto da ação da categoria médica que visava resguardar em termos legais o monopólio do exercício da "arte de curar". Além da condenação ao espiritismo, à magia e outras práticas, o Código Penal previa punições para o simples exercício da medicina sem títulos acadêmicos (art. 156) e o crime de curandeirismo, ou seja, a aplicação ou prescrição de substâncias com fins terapêuticos (art. 158).

Para além da criminalização inscrita no Código Penal de 1830, que se manteve na legislação vigente, cabe atentar para a existência dos códigos de posturas municipais,' através dos quais se positivou as investidas policiais aos terreiros e casas de santo na segunda metade do século XX.

Embora na atualidade tenhamos políticas públicas que se destinem a promover a liberdade religiosa e o combate à intolerância, são inúmeros os registros de tentativas de cerceamento à livre expressão religiosa. A maioria das denúncias são relacionadas às tradições de matriz africana, e esse aspecto está diretamente vinculado com o histórico de criminalização. A expansão do neopentecostalismo no território brasileiro exerce um papel relevante na permanência da intolerância religiosa vivenciada pelas tradições de

6 A chamada "Escola Nina Rodrigues", assim conhecida pela relevância que teve na fundação da antropologia e da medicina legal no Brasil foi responsável pela difusão de estudos calcados naquilo que hoje se denomina "racismo científico" e "criminologia biológica". Sobre o legado de Nina Rodrigues ver: FERRETI, S. Nina Rodrigues e a Religião dos Orixás. Gazeta Médica da Bahia, 2006; 76 . P 54 - 59. 
matriz africana. Contudo é interessante notar que o neopentecostalismo absorve características dessas expressões religiosas, adotando o que Ari Pedro Oro

(2005, pág.68 ) denomina como "religiofagia", ou seja, a apropriação e reelaboração que as igrejas neopentecostais, em especial a Igreja Universal do Reino de Deus, fazem sobre os elementos de crenças de outras igrejas e religiões.

Essa é uma estratégia que auxilia na cooptação de sujeitos que outrora pertenciam as tradições de matriz africana. Segundo SILVA (2007, pág.27):

O neopentecostalismo, em consequência da crença de que é preciso eliminar a presença e a ação do demônio no mundo, tem como característica classificar as outras denominações religiosas como pouco engajadas nessa batalha, ou até mesmo como espaços privilegiados da ação dos demônios, os quais se "disfarçariam" em divindades cultuadas nesses sistemas. É o caso, sobretudo, das religiões afro-brasileiras, cujos deuses, principalmente os exus e as pomba giras, são vistos como manifestações dos demônios. Uma outra face desse processo é, paradoxalmente, a "incorporação" da liturgia afro-brasileira nas práticas neopentecostais de algumas igrejas.

Existe a disseminação de um discurso de ódio religioso contra as expressões religiosas de matriz africana. Esse discurso é difundido pelas Igrejas, em especial pela Igreja Universal do Reino de Deus, detentoras de forte poder político e midiático ${ }^{7}$, sendo a mídia utilizada no trabalho de proselitismo em massa e propaganda religiosa (SILVA,2007).

O enfrentamento à intolerância religiosa na seara legislativa: o Código de Proteção aos Animais e o PL 21/2015 da Assembleia Legislativa do Estado do Rio Grande do Sul.

O percurso de intolerância que vem sendo experimentado pelas expressões religiosas das tradições de matriz africana no estado do Rio Grande do Sul, apresenta uma característica peculiar que é a frequente proposição de projetos de leis que ferem a liberdade religiosa. Entre inúmeros projetos de leis de cunho municipal, como códigos de posturas, merece destaque dois projetos que tramitaram recentemente na Assembleia Legislativa do Estado do Rio Grande do Sul (ALERGS) e que tem conexão entre si: o

\footnotetext{
7 Os ataques às tradições de matriz africana promovidos pelas igrejas neopentecostais são promovidos também nas emissoras de radiodifusão. Programas como Fala que eu te escuto, transmitidos em canais de televisão aberta de propriedade da Igreja Universal do Reino de Deus, retratam as religiões de matriz africana invariavelmente atribuídas com aspectos depreciativos. Dessa forma, os fiéis neopentecostais são inflados não apenas durante os cultos, mas também através dos meios de comunicação, ao vilipêndio e a outras formas de violência aos símbolos e aos sujeitos que vivenciam as tradições de matriz africana.
} 
Código Estadual de Proteção aos Animais e o PL 21/2015, projetos que, cada um à sua maneira, visavam eliminar o sacrifício de animais nas liturgias do batuque, impossibilitando a existência das mesmas visto a relevância que o sacrifício animal tem nessa tradição.

A imolação de animais nas expressões religiosas das tradições de matriz africana é a forma com que se estabelece a comunicação entre os adeptos e as divindades cultuadas, um fundamento sagrado com múltiplos significados míticos que se configuram enquanto pilares dessa religião. É um ritual de renascimento em que a importância da vida animal supera o princípio do consumo para a alimentação humana. Ao colocar animal e humano em extensão, implicados um no outro, esse ritual põe o homem em contato com potências complexas de sua existência enquanto "ser vivo". Assim, o abate sacralizado de um animal também encerra o ciclo de uma vida humana, que se reinicia fortalecida pela nutrição dos deuses e da comunidade. Mas isso só é possível graças a uma cosmologia que enxerga a vida como fenômeno coletivo, prevista pela interdependência entre animais humanos e não-humanos, plantas, matas, águas, solo, ventos, enfim a natureza e o meio ambiente. (LOPES, 2005).

O mencionado Código Estadual de Proteção aos Animais representou uma ameaça à continuidade das cosmologias referentes às expressões religiosas das tradições de matriz africana no Rio Grande do Sul. O texto original proibia o sacrifício e o projeto apresentado permitia uma interpretação que possibilitaria intervenções policiais e criminalização dos cultos.

Partiremos do texto proposto em 2003, e não do projeto original, visto que este foi o texto que veio a público com maior visibilidade e ensejou todos os desdobramentos que seguiram. Eis:

É vedado:

I - ofender ou agredir fisicamente os animais, sujeitando-os a qualquer tipo de experiência capaz de causar sofrimento ou dano, bem como as que criem condições inaceitáveis de existência;

IV - não dar morte rápida e indolor a todo animal cujo extermínio seja necessário para o consumo. (RIO GRANDE DO SUL, 2003)

As lideranças das expressões religiosas das tradições de matriz africana situadas no Rio Grande do Sul, logo perceberam que essa norma tratava de supressão aos seus 
pressupostos civilizatórios e modo de vida. A proposta surgiu de um deputado neopentecostal, pastor da Igreja do Evangelho Quadrangular, Manoel Maria dos Santos (PTB/RS), materializando uma das formas de ataque utilizadas pelas igrejas evangélicas frente às expressões religiosas de matriz africana: a proposição de instrumentos legislativos que criam obstáculos às formas de culto utilizadas pelas expressões religiosas das tradições de matriz africana. $\mathrm{O}$ termo ataque é aqui utilizado conforme a definição dada por SILVA (2007, pág. 9):

[...] uma investida pública de um grupo religioso contra outro. Certamente que as razões deste ataque se justificam, do ponto de vista do "atacante", por convicções religiosas. E, desse ponto de vista, o termo é visto como sinônimo de "evangelização", "libertação" etc. Faz parte, aliás, de um léxico "belicoso" (no qual figuram outros termos como "batalha", "guerra santa", "soldado de Jesus" etc.) presente no discurso neopentecostal que descreve suas ações contra o demônio e os sistemas religiosos que supostamente o cultuam. Do ponto de vista dos grupos afro-brasileiros, obviamente o ataque possui inúmeros outros significados, sendo visto como sinônimo de "intolerância religiosa", "preconceito", "discriminação" etc.

A articulação das lideranças do povo de terreiro ${ }^{8}$ com outras entidades da sociedade civil e com deputados notadamente defensores dos diretos humanos foi fundamental para que a lei original fosse modificada. O deputado estadual Edson Portilho (PT/RS) apresentou uma emenda que proporcionou que não pudesse haver interpretações legais que permitissem a limitação do direito ao culto. Importa mencionar que o projeto original do Código Estadual de Proteção aos Animais do Estado do Rio Grande do Sul foi apresentado no início da década de 90 e a demora na sua apreciação se deu em razão de que em suas primeiras versões mencionava questões relativas à caça amadora no território gaúcho, prática que era permitida até 2008. Nesse sentido, BARBOSA (2012, pág.68):

O projeto da lei 447/91 que instituiria o "Código Estadual de Proteção aos Animais e dá outras providências”, CEPA, embora apresentado por

\footnotetext{
8 As lideranças de matriz africana, especialmente no Rio Grande do Sul, se autodenominam enquanto povo de terreiro. São coletividades que apresentam ligação com as tradições de matriz africana, possuindo uma organização social específica baseada nos valores do respeito à ancestralidade e a relação intrínseca com o meio ambiente. Existem outras denominações como: povo de santo, povo de axé e povos tradicionais de matriz africana, mas todas elas refletem as caracterizações anteriormente descritas.
} 
Manoel Maria na Assembleia Legislativa em 1991, no dia 04 de outubro, data em que se comemora o Dia Universal dos Animais, demorou mais de dez anos para ser efetivamente aprovado. Segundo Manoel Maria, devido à regulamentação da caça nas primeiras versões do Código, havia dificuldade de ele ser aprovado. Na época, o Rio Grande do Sul era o único estado brasileiro onde a caça amadorística era permitida. Suprimida boa parte dos itens que visavam dificultar a caça, abriu-se caminho para que o Código fosse aprovado. Reformulado, assim, várias vezes, em maio de 2003, foi sancionado como projeto de lei 230/99, votado e aprovado na Assembleia Legislativa do Rio Grande do Sul, transformado na lei11.915, que instituía o Código Estadual de Proteção aos Animais.

A emenda proposta pelo deputado Edson Portilho (PT/RS) foi amplamente discutida pelas autoridades religiosas das tradições de matriz africana e pelos representantes do executivo e legislativo gaúcho à época, restando aprovado com 32 votos a favor e 2 votos contrários. Contudo, as entidades ligadas à defesa da vida animal propuseram Ação Direta de Inconstitucionalidade através da Procuradoria Geral da Justiça, perante o Tribunal de Justiça do Rio Grande do Sul, sustentando que a lei versava sobre matéria penal e a ampla maioria dos desembargadores considerou a emenda constitucional. A partir da declaração de constitucionalidade da emenda, se esperava que as polêmicas jurídicas a respeito da questão do sacrifício animal realizados nas manifestações religiosas das tradições de matriz africana estariam encerradas. Porém, no ano de 2015, a deputada estadual Regina Becker Fortunati (PDT/RS) apresentou projeto lei 21/2015 que visava alterar o Código Estadual de Proteção aos Animais. $^{9}$

A proposição da deputada reascendeu os debates sobre liberdade religiosa, direito ao culto, racismo institucional e valorações sobre a vida. A justificativa apresentada visava apenas impedir que as expressões religiosas das tradições de matriz africana pudessem continuar utilizando suas liturgias sagradas de forma plena, conforme percebe-se no que segue:

A Constituição Federal tanto estabelece o respeito à liberdade religiosa

\footnotetext{
Projeto de Lei $n^{\circ} 21$ /2015. Deputado (a) Regina Becker Fortunati. Altera a Lei 11.915, de 21 de maio de 2003, que institui o Código Estadual de Proteção aos Animais, no âmbito do Estado do Rio Grande do Sul, e revoga a Lei $n^{\circ} 12.131$, de 22 de julho de 2004. Art. $1^{\circ}$ - Ficam revogados o parágrafo único do art. $2^{\circ}$ da Lei 11.915 , de 21 de maio de 2003, e a Lei n ${ }^{\circ} 12.131$, de 22 de julho de 2004. Art. $2^{\circ}$ - Esta Lei entra em vigor na data de sua publicação. Deputado (a) Regina Becker Fortunati (RIO GRANDE DO SUL, 2015).
} 
quanto garante a todos o direito à vida. $\mathrm{O}$ reconhecimento dos Direitos Animais é uma evolução da sociedade, e esta tem manifestando sua inconformidade diante de práticas colidentes em que se verifica o interesse de segmentos sobrepondo-se aos da coletividade, no que concerne o sacrifício de animais. O uso de animais para os mais variados fins ultrapassa séculos e é fato que a consciência de que a todos cabe defender a vida, o bem maior, tem resultado em significativas mudanças na conduta do ser humano. É crescente a opção em se abster do uso de animais como alimento e cada vez menor é a aceitação que lhes resulte a morte para o atendimento das necessidades humanas, incluindo neste roll as experiências em laboratórios, o confinamento com privação de liberdade, e, igualmente, os rituais religiosos. A externação da fé não pode afrontar os direitos alheios, visto que não é absoluta e, na atualidade, a citada prática de liturgias já não se pacifica com a consciência da sociedade em permanente evolução e a quem a Carta Magna determinou, tanto quanto ao Poder Público, o dever de defender e proteger os seres vivos e o meio ambiente. O sacrifício de animais em rituais religiosos em muito inquieta a sociedade e os preceitos de respeito e da boa convivência harmônica e pacífica precisam ser restabelecidos. Além da inconformidade com a morte de animais para este fim, é imensurável o sofrimento que advém do constrangimento a que somos submetidos, encontrando os corpos em putrefação utilizados nas oferendas em locais públicos, tais como as ruas e praças de nossas cidades, inclusive o de seres que nossa cultura sequer assimila como alimento. Há de se considerar a questão da saúde pública, colocada em risco diante da decomposição orgânica dos animais que são vitimados nos rituais em nome da fé. Diante destas considerações e ao encontro dos anseios de mudanças que coadunam com a evolução da consciência da coletividade, apresentamos a presente proposição para que seja acolhida através da revogação da Lei 12.131/04. (RIO GRANDE DO SUL, 2015)

A justificativa apresenta resquícios dos ideais higienistas, sanitaristas e evolucionistas que foram base para a criminalização e controle destas tradições. A deputada promoveu uma colisão entre a liberdade religiosa e o direito à vida como se esses pressupostos fundamentais fossem antagônicos, quando o que se dá é a complementaridade deles. A liberdade religiosa é erigida enquanto direito humano, entre outras razões, para que não se limite a construção da identidade e a cidadania dos povos. É sintomático que, em nenhum momento a justificativa do projeto de lei menciona outras expressões religiosas que também atribuem significados míticos ao consumo de carne. Conforme DIAS (2010, p. 187) em artigo sobre o significado do peixe para os judeus: 
Todos os animais que são alvo do consumo humano passavam por um processo prévio de sacrifício, em que uma parte determinada era oferecida aos deuses, e a restante se destinava a ser comercializada, ou directamente ao consumidor final. Nos aspectos que se prendem com o consumo alimentar, o peixe, e as espécies marinhas em geral, não passavam por um processamento intermédio de sacrifício religioso. É certo que a ocasião do sacrifício das espécies cárneas se tornou, entretanto, dado o volume de consumidores e a frequência dos actos de sacrifício, uma realidade mecanizada, em que o agente, o sacerdote, retirava o seu sustento do volume de sacrifícios efectuado.

Atualmente, na maioria das tradições judaico - cristãs, não se oferta parte da carne sacralizada aos deuses, contudo o conteúdo litúrgico permanece, caracterizando uma ingestão sagrada em ocasiões específicas, como é o caso da quaresma e da semana santa. Porém, para as expressões religiosas das tradições de matriz africana, a sacralização continua exercendo um significado de comunicação com o sagrado, que remete inclusive a renovação das forças vitais, e, portanto, com o direito à vida. É exatamente em virtude desta concepção que a alimentação para as expressões religiosas das tradições de matriz africana é entendida como um direito sagrado, sendo reconhecida pela UNESCO e pelo Ministério de Desenvolvimento Social e Combate à Fome a contribuição dos terreiros em matéria de políticas públicas de segurança alimentar e nutricional (MDS, 2011).

Todo o conteúdo exposto na justificativa apresentada pela deputada Regina Becker Fortunatti já havia sido amplamente debatido, inclusive pelo Poder Judiciário do estado do Rio Grande do Sul, quando da proposição da emenda ao Código Estadual de Proteção aos Animais, em 2003. Sendo assim, o que se observa é uma continuidade dos conflitos entre normas de caráter aparentemente ambiental, propostas por deputados neopentecostais, e as expressões religiosas das tradições de matriz africana. No entanto, nesse processo, se possibilitou uma cooperação entre religião e Estado que se estabelece de forma diferenciada, posto que, se no passado, essa cooperação estava destinada apenas a Igreja e aos fundamentos morais de origem judaico-cristã, as estratégias e a presença pública das expressões religiosas das tradições de matriz africana para a não aprovação do referido Projeto consubstanciaram uma interação entre a comunidade religiosa e o Estado.

O parecer contrário ao PL 21/2015, apresentado pela Comissão de Constituição 
e Justiça da Assembleia Legislativa do Estado do Rio Grande do Sul é um instrumento relevante no que tange o combate à intolerância religiosa em sede legislativa. No texto, o relator, que admite ser católico, arrola preceitos bíblicos sobre a imolação e fundamenta a orientação contrária ao projeto com base no livro bíblico do Gênesis. Segue excerto do parecer:

Peço licença aos meus colegas Deputados para também fundamentar minha decisão não somente de forma constitucional, mas também de forma pessoal, humana, com amparo no ato do próprio Papa Francisco, que, há poucos dias, foi rezar numa mesquita muçulmana, em Istambul, na Turquia, num edificante exemplo de diálogo inter-religioso e respeito às diferenças. Quanto à utilização de animais, vale lembrar os valores de tradição judaico-cristã e a presença de ritos de oblação de animais na religião. Na Bíblia, livro do Gênesis, capítulo 22, versículos 1 a 14, o patriarca Abraão ofereceu a Deus um cordeiro em holocausto. Antes disso, ainda no Gênesis, disse Deus ao homem e à mulher: crescei, multiplicai-vos e dominai a terra... A utilização de animais não consta nas Escrituras como um gesto de crueldade. Seria impiedoso consumir a carne de animais como alimento? (RIO GRANDE DO SUL, 2015)

O sacrifício animal, não é exclusividade característica das expressões religiosas das tradições de matriz africana, como bem demonstrado pela argumentação do parecer contrário ao Projeto Lei. Por mais que a maioria das tradições judaico-cristãs tenham se abstido do sacrifício ritual, algumas religiões ocidentais ainda apresentam esse traço na sua liturgia. Os abates kosher e halal são exemplos de sacralizações rituais que são exercidas por outras tradições religiosas, as quais não eram mencionadas no Projeto de Lei analisado.

Nesse sentido, há uma valoração que expressa não só a intolerância religiosa frente aos cultos das tradições de matriz africana, como também se manifesta o racismo institucional. Embora as tradições de matriz africana, na atualidade, estejam reconfiguradas mundo afora em consequência da diáspora negro - africana, a origem das mesmas faz com que integrem a identidade social da negritude brasileira, constituindose enquanto territórios de resistência, da mesma forma que as comunidades quilombolas.

Há também, na ausência de menções aos sacrifícios animais islâmicos e judeus, a prevalência do reconhecimento de determinas expressões religiosas em detrimento de outras. Nesse caso específico é importante ressaltar que a indústria de carne tem se 
valido do abate religioso para garantir o mercado estrangeiro, e que a própria campanha da deputada Regina Becker Fortunatti foi, em parte, financiada pela JBS/ S.A, empresa do ramo alimentício que controla as marcas Friboi e Big Frango, as quais exploram os setores de carne bovina, aves, suínos, ovinos e couro. Ou seja, há uma diferença de tratamento entre distintas tradições religiosas.

Por todo o exposto, fica evidenciado que por trás do discurso de proteção ambiental e defesa dos animais o que se dá é a tentativa de obstaculizar a existência e permanência das expressões religiosas das tradições de matriz africana no Estado do Rio Grande do Sul. Ademais, um território que é celebrado e internacionalmente conhecido por tradições que celebram a indústria pecuária, o consumo de carne em grandes eventos que rememoram aspectos históricos da trajetória dos gaúchos, havendo notoriedade acerca das tradições do churrasco e do bom chimarrão, criminalizar a ingestão do mesmo alimento, apenas porque este é concebido de forma diversa da hegemônica é contraditório.

Reconhece-se que há um conflito entre o direito à vida animal e a liberdade religiosa, por mais que não seja o que está de fato estabelecido neste caso, sendo um verdadeiro jogo de poder, no qual a atuação das bancadas neopentecostais reveste-se de um conservadorismo que afronta princípios fundamentais consolidados pelas normas jurídicas pátrias. Porém, respeitar e proteger a existência das expressões religiosas das tradições de matriz africana no Brasil é consolidar o direito à memória coletiva, ao território, ao alimento e ao patrimônio cultural imaterial brasileiro. Portanto, um dever do Estado que merece ser garantido e efetivado, ensejando a construção de políticas públicas robustas que eliminem do cenário sócio-político a continuidade de ações racistas que afrontam os princípios constitucionais.

\section{Considerações finais}

A construção da laicidade no território brasileiro é oriunda de um processo de acepções de modelos legislativos e influências políticas de outros Estados. O que definiu os rumos da formação do Estado laico brasileiro foi a pressão exercida por nações cujas relações com o Brasil eram marcadas pela dependência econômica e política e pelo colonialismo. O Estado brasileiro experimenta uma laicidade que é questionada todo momento, tanto por parte dos movimentos sociais organizados, quanto 
pela sociedade civil, sendo frequentes as críticas e estudos sobre a presença de símbolos religiosos nas repartições públicas, a vigência do ensino religioso hegemônico nas escolas (públicas e privadas) e a relevância dos valores morais judaico-cristãos na produção de normas e no âmbito sócio-político.

Não obstante, as avenças que tratam sobre liberdade religiosa apresentam a importância de estar relacionados a uma luta por reconhecimento de direitos por parte de setores oprimidos socialmente; dessa forma esse pressuposto fundamental apresenta relevância para as expressões religiosas das tradições de matriz africana. A comunidade negra experimentou toda a forma de violência e tolhimento de direitos, reflexo da escravização e colonialismo e, assim, o racismo institucional permanece criando dificuldades para a equidade racial, perceptíveis na forma com que o sistema jurídico em nosso país aborda as questões intrínsecas aos pressupostos civilizatórios da população negra.

Ao alvorecer da Constituição Federal de 1988, as normas infraconstitucionais que limitavam a liberdade religiosa revogaram-se tacitamente, devido à liberdade religiosa ser erigida ao status de princípio fundamental. Contudo, esse fato não significou o fim dos conflitos e tensões experimentados pelos sujeitos que vivenciam as tradições religiosas de matriz africana. As bancadas evangélicas têm exercido seu proselitismo nas produções de leis, criando óbices aos cultos religiosos das tradições de matriz africana e promovendo ódio religioso e racismo em seus discursos.

As articulações do povo de terreiro ainda demandam uma organização mais robusta. Ao contrário do que se tem com a Igreja Católica, institucionalmente representada na esfera pública, as expressões religiosas de matriz africana têm poucas entidades constituídas. Nesse sentido, é cogente a formulação de políticas públicas e ações estatais que estabeleçam um cenário de promoção da diversidade, da livre expressão religiosa e da laicidade do Estado.

A análise do PL 21/2015, desde a proposição até o arquivamento, permitiu concluir que há um retrocesso no que tange às liberdades religiosas, marcadamente expressado através do racismo institucional. A forma com que a União se preocupa em adequar a produção de carne para determinadas expressões religiosas que, reconhecidamente, são manifestadas por sujeitos detentores do capital financeiro é um dado que permite estabelecer um comparativo sobre o quão imbricado estão as questões 
abordadas no presente trabalho. Se não há um tratamento isonômico por parte do Estado a respeito das múltiplas concepções de vida, valores morais, pensamentos e modos de vida, não há o que se falar em democracia plena e, inevitavelmente, há falência da liberdade religiosa e do Estado Laico. 


\section{Referências}

BRASIL. Ministério do Desenvolvimento Social e Combate à Fome. Alimento: Direito Sagrado - Pesquisa Socioeconômica e Cultural de Povos e Comunidades Tradicionais de Terreiros. Brasília: SAGI, 2011. 200p

Constituição Política do Império do Brazil. 1824. Disponível em: http://www.planalto.gov.br/ccivil_03/Constituicao/Constituicao24.htm. Acesso em: 03 mar. 2015

Código Criminal do Império do Brazil. 1830. Disponível em: http://www.planalto.gov.br/ccivil_03/leis/LIM/LIM-16-12-1830.htm Acesso em: 03. Set. 2015

Código Penal dos Estados Unidos do Brazil. 1890. Disponível em: http://legis.senado.gov.br/legislacao/ListaPublicacoes.action?id=66049 Acesso em: 03 mar. 2016.

Constituição da República Federativa do Brasil, de 05 de out. De 1988. Disponível em: http://www.planalto.gov.br/ccivil_03/constituicao/constituicaocompilado Acesso em: 05 mar. 2016.

Decreto Presidencial 4.887/2003 de 20 de novembro de 2003 - Regulamenta o procedimento para identificação, reconhecimento, delimitação, demarcação e titulação das terras ocupadas por remanescentes das comunidades dos quilombos de que trata o art. 68 do Ato das Disposições Constitucionais Transitórias. In: Diário Oficial da União Edição Número 227 de 21/11/2003.

CARVALHO, Nara Pereira. A formação da liberdade religiosa: Particularidades e Vicissitudes no Brasil. 2011. 169 f. Dissertação (Mestrado em Direito) - Faculdade de Direito, Universidade Federal de Minas Gerais, Belo Horizonte, 2011.

CASAMASSO, Marco Aurélio Lagreca. Estado, Igreja e liberdade religiosa na "Constituição política do Império do Brazil”, de 1824. In: Encontro Nacional do

CONPEDI,19, 2010, Fortaleza. Anais...Fortaleza: Fundação Boiteux, 2010, p. 6167 - 6176.

CURY, C.R.J. Ensino religiosa na escola pública: o retorno de uma polêmica recorrente. Revista Brasileira de Educação, n.27, p. 183- 213

JÚNIOR RANQUETAT, Cesar Alberto. Laicidade à brasileira: um estudo sobre a controvérsia em torno da presença de símbolos religiosos em espaços públicos. 2012. $321 \mathrm{f}$. Tese (Doutorado em Antropologia) - Instituto de Filosofia e Ciências Humanas, Universidade Federal do Rio Grande do Sul, Porto Alegre, 2012

GIUMBELLI, E. A presença do religioso no espaço público: modalidades no Brasil. Religião e Sociedade, v.28, n.2, p.80-101, 2008.

O "baixo espiritismo" e a história dos cultos mediúnicos. Horizontes

Antropológicos. Porto Alegre, v. 9, n. 19, p. 247-281, 2003

GONÇALVES, Antônio Batista. Direitos Humanos e (in) tolerância religiosa. Laicismo proselitismo-fundamentalismo - terrorismo.2011. 227f. Tese (Doutorado em Filosofia do Direito). Pontífice Universidade Católica de São Paulo, São Paulo, 2011.

LENZA, Pedro. Direito constitucional esquematizado. São Paulo: Saraiva, 2013. 1408.

LOPES, Nei. Kitabu: O livro do saber e do espírito negro africanos. Rio de Janeiro: Editora Senac Rio, 2005.

NICOLINI, Marcos Henrique de Oliveira. Laicidades articuladas sócio - historicamente. Estudos de Religião, v. 25, n.41, p. 235-244, 2011.

ORO, Ari Pedro. A laicidade no Brasil e no Ocidente: algumas considerações. Civitas, v.11, n.2, p.221-237, 2011

RIO GRANDE DO SUL. Decreto $n^{\circ} 43.252$, de 22 de julho de 2004. Regulamenta o artigo $2^{\circ}$ 
da lei 11.915, de 21 de maio de 2003. Disponível em:

www.al.rs.gov.br/legis/M010/M0100099.ASP?Hid_Tipo. Acesso em:10. mar. 2016

Lei n. ${ }^{\circ} 11.915$, de 21 de maio de 2003. Institui o Código Estadual de Proteção aos Animais. Disponível em:

http://www.al.rs.gov.br/legiscomp/arquivo.asp?Rotulo=Lei\%20n\%BA\%2011915\&idNor ma $=32 \&$ tipo=pdf Acesso em: 12 mar. 2016

. Lei n. ${ }^{\circ} 12.131$, de 22 de julho de 2004. Acrescenta parágrafo único ao artigo $2^{\circ}$ da Lei $\mathrm{n}^{\mathrm{o}} 11.915$, de 21 de maio de 2003. Disponível em: http://www. al.rs.gov.br/filerepository/repLegis/arquivos/12.131.pdf Acesso em: 12 mar. 2016

. Assembleia Legislativa. Projeto de Lei $n^{\circ} 21 / 2015$. Altera a Lei $n^{\circ} 11.915$, de 21 de maio de 2003, que institui o Código Estadual de Proteção aos Animais, no âmbito do

Estado do Rio Grande do Sul, e revoga a Lei no 12.131, de 22 de julho de 2004.

Disponível

em:

http://www.al.rs.gov.br/legislativo/

ExibeProposicao/tabid/325/SiglaTipo/PL/NroProposicao/21/AnoProposicao/2015/Orige m/Px/Default. Acesso em: 06 mar. 2016

RODRIGUES, Raymundo Nina. Os africanos no Brasil [online]. Rio de Janeiro: Centro Edelstein de Pesquisas Sociais, 2010. 303 p. ISBN: 978-85-7982-010-6. Disponível em: http://static.scielo.org/scielobooks/mmtct/pdf/rodrigues-9788579820106.pdf . Acesso em 20.mar. 2016

SAAD, Luísa Gonçalves. "Fumo de Negro": a criminalização da maconha no Brasil (c. 1890 1932). 2013. 147f. Dissertação (Mestrado em História) - Programa de PósGraduação em História Social. Universidade Federal da Bahia, Salvador, 2013.

SILVA, V.G. Neopentecostalismo e religiões afro-brasileiras: Significados do ataque aos símbolos da herança religiosa africana no Brasil contemporâneo. Mana, v. 13, n. 1, p. 207-236, 2007.

Recebido: $15 / 09 / 2017$

Received: 09/15/2017

Aprovado: $23 / 11 / 2017$

Approved: 11/23/2017 